\title{
INNOVATIONS CONNECTED TO METHANOL IN THE SERVICE OF BLUE ECONOMY
}

\author{
Judit Toth ${ }^{* *}$, Sandor Szlovák', Robert Magda² \\ 'Doctoral School of Management and Business Administration, Faculty of Economics and Social Sciences, Szent Istvan University, \\ Gödöllö, Hungary \\ ${ }^{2}$ Institute of Economics, Law and Methodology, Faculty of Economics and \\ Social Sciences, Szent István University, Gödöllő, Hungary
}

\begin{abstract}
The model of Blue Economy by G. Pauli is inspired by nature. Its main task is to develop innovative methods based on the use of available resources and the use of nature-based solutions. The principle of Blue Economy requires close cooperation of research and development and business activities; and it seeks implementation options in the structure of local economies. Based on the theory known as 'blue economy', in order to overcome certain problems of mankind - for example, energy production and consumption -, we must recognize and use some methods given to us by nature. This may be provided to us by new innovations that think according to system theory, that is, occupy the exceptionally effective self-regulating processes of nature in the economy. Methanol may play a key role in succeeding sustainability regarding nature, economy and society. Methanol economy can contribute to reducing human impacts on Earth's climate by reversing atmospheric carbon dioxide, and it provides the opportunity to get rid of our dependence on dwindling oil and gas resources.
\end{abstract}

Keywords: Blue Economy, greenhouse gas, renewable methanol, waste

As Herman Daly puts it, 'sustainable development is a progressive social betterment without growing beyond ecological carrying capacity'. Therefore, the fundamental objective of development is to ensure the potentials of reasonable conditions for everyone and for present and future generations equally; which can only be possible if natural resources are utilized in a sustainable way, harmful impacts and especially irreversible changes in the environment are avoided.

According to the statement of the World Scientific Academies, 'Sustainability means to satisfy the present needs of humanity together with the preservation of the environment and other natural resources for the generations of the future.' (A Transition to Sustainability. A statement of the World Scientific Academies, Tokyo, 2000).

From another point of view, sustainable development also means that society formulates liveable and feasible ideas for itself, taking into consideration economic, social as well as environmental aspects of human activities (Pope et al., 2004). These so-called three pillars are taken into account by both individuals and corporations in the course of decisionmaking. In this form, it was first published by Adams (Adams, 2006).

Economic pillar is supposed to advance realistic economic growth of corporations. Social pillar includes the attitude of corporations and its consequences towards society: conditions of employees (working conditions, level of compensation, etc.), conditions of suppliers, customers, local communities and the society. Besides, this pillar covers development levels of society. Environmental pillar is supposed to assure cooperation and compliance between social activities of businesses and maintaining biodiversity and the ecosystem.
Environmental pillar includes evaluation concerning impacts of social activities and products of companies according to the following points (Mailler, 2008):

$\square$ using slowly renewable resources or resources that have the ability to be renewed with difficulties;

$\square$ aspects of appropriate production and waste management;

$\square$ minimize pollutant emissions.

In fact, the equal role of the three dimensions is emphasized here.

In other words, followers of the 3-pillar model are seeking a prudent way of using natural resources while keeping the need for environmental protection in mind. According to Wood (Wood, 2002), sustainable development can be achieved by finding a balance between economic, social and environmental aspects of human activities. Achieving economic development without paying attention to aspects of society cannot be regarded as sustainable development. Likewise, we cannot note that development is sustainable when environmental protection is supported more vigorously than necessary and therefore economic activities are sacrificed. As a matter of fact, equal roles of the three dimensions are emphasized with the above.

\section{Materials and methods}

In the following sessions, the paper focuses on sustainability and those innovations which are connected with the usage of methanol in the service of blue economy. The methodological approach is mainly descriptive. The analysis will be based on relevant statistical data from secondary sources from national and international literature. 


\section{Results and Discussion}

\section{The Role of Innovation in Achieving the Objectives of Sustainable Development}

Neoclassical economists regarded natural resources - air and water - as unrestricted availability. In his writings, Arthur Pigou was the first to mention the problem of environmental pollution in economic theory. He introduced the concept of externality in his work, The Economics of Welfare (Pigou, 1920). As a negative external impact, environmental pollution results in welfare losses for society, which can be compensated for and stopped via governmental intervention by adjustment of the market. Intervention refers to taxes laid on pollution, which aim to improve efficiency of the use of resources (allocative efficiency), to reduce production or consumption causing pollution to the socially optimal level and to lower environmental pollution itself to the socially optimal level. Pollution taxes indicate scarcity of resources and encourage companies to innovate. Companies need to strive for fast adaptation and those capable of doing so will gain long-term sustainable competitive advantage over others. Adaptation to ecological constraints is a part of innovation capability (Porter, 1991). By joining international conventions, member states can effectively encourage environmental compliance of their businesses within their national legislation. Well-drafted environmental standards advance companies to reorganize their activities and develop new technological solutions that do not only reduce pollution and result in more efficient use of resources but can also help them gain the market-leader role through innovations by deploying the advantage of being the first one to react. Based on a systemic approach, innovations serving the principles of sustainable development can be divided into three categories:

At the level of system optimization, the structure of existing production and consumption systems remains unchanged and its gradual development is simply achieved. This category includes the application of innovations and end-of-pipe solutions to improve eco-efficiency of various products, services, and production and consumption systems.

At the level of system redesign, reorganization of supply and consumption systems, modification of certain subsystems and interactions are usually carried out by means of functional, sustaining innovation, within the frameworks of the existing context.

System innovation is the level where not only persistent optimization of products and/or services and processes takes place under the terms of the existing infrastructure and institutional framework, but also the whole system - i.e. constituents, their relationships and interactions - is changed. It requires emergence and spread of innovations that break with prevailing solutions and principles and help to make the whole system more sustainable (Tukker and Tischner, 2006).

\section{The Philosophy of Blue Economy}

The model of Blue Economy by G. Pauli is inspired by nature. Its main task is to develop innovative methods based on the use of available resources and the use of nature-based solutions. The principle of Blue Economy requires close cooperation of research and development and business activities; and it seeks implementation options in the structure of local economies.

Some Principles of Blue Economy:

$\square$ Natural systems cascade nutrients, matter and energy - waste does not exist. Any by-product is the source for a new product.

$\square$ Nature provides room for entrepreneurs who do more with less. Nature is contrary to monopolization.

$\square$ In nature, the constant is change. Innovations take place in every moment.

$\square$ Natural systems are non-linear.

$\square$ In nature, everything is biodegradable - it is just a matter of time.

$\square$ In natural systems, everything is connected and evolving towards symbiosis.

$\square$ In nature, one process generates multiple benefits.

$\square$ Natural systems share risks. Any risk is a motivator for innovations.

$\square$ Nature is efficient. Therefore, sustainable businesses maximize use of available material and energy, which reduces the unit price for the consumer.

$\square$ Nature searches for economies of scope. One natural innovation carries various benefits for all.

$\square$ Respond to basic needs with what you have, introducing innovations inspired by nature, generating multiple benefits, including jobs and social capital, offering more with less (Pauli, 2015).

Blue Economy, in contrast to Green Economy, does not seek a way out by the overwhelming application of means of persuasion from above, but rather in the active innovation activity that would offer decent subsistence to many people. Table 1 compares Green Economy with Blue Economy.

\section{How Methanol Serves Blue Economy Objectives}

The concept of methanol economy has several opportunities and advantages. Methanol can be produced employing any type of energy sources, including alternative energy resources. Methanol is the most convenient way to store and distribute energy: it is an excellent fuel in itself and it is a raw material for synthetic hydrocarbons and their derivatives. Reversible energy can be safely and comfortably stored, and energy can be transported easily with liquid methanol.

In addition, methanol industry contributes to reducing human effects in Earth's climate by recycling atmospheric carbon dioxide. The properties of methanol and its potential for production explain why its research into alternative energy resources has become a top priority. Methanol is an easy-to-use liquid; therefore, its transportation is much simpler than the transportation of hydrogen which is also treated as an alternative.

Production and use of hydrogen can be solved but its transportation is much more difficult as atmospheric pressure would require enormous hydrogen tanks. Liquefaction, on high pressure and at low temperatures according to current technologies, does not fundamentally change the

Table 1 Blue is the new green

\begin{tabular}{|c|c|}
\hline Green economy & Blue economy \\
\hline wind, solar, battery, biomass, next energy technology creation & water cleaning, monitoring, conservation products and services \\
\hline building retrofits, turbine machining, solar panel production, transit-building: "green collar jobs" & building retrofits, water infrastructure repair, Filter making, "blue-collar" jobs \\
\hline "greenways", parks, open-space: "green" places & "blue-ways", wetland preservation, waterfront renewal, water trails \\
\hline green roofs, recycling, local food: "green" culture & rain-gardens, grey-water systems, smart water lifestyles \\
\hline
\end{tabular}

Source: Austin, 2014 
situation; moreover, it considerably increases the energy demand of transportation.

There is a sufficient amount of releasable energy for the power demand of an average home for two to three months in a single tank of petrol; its storage would require a battery that weighs about $1,000 \mathrm{~kg}$. The single good solution for storage problems can be if energy is not stored in direct electrical forms.

The fact that electric energy can be directly produced in a so-called fuel cell by using methanol is of great importance for the methanol industry. Methanol-powered cars of the future are planned to be powered by electric motors and fuel cells. A fuel cell is an electrochemical galvanic cell capable of converting chemical energy of the fuel contained therein directly into electric energy.

The difference between fuel cells and galvanic cells is that whereas battery needs to be replaced (or recharged) after being used in galvanic cells, fuel cells can be constantly supplied with new fuel. Fuel is liquid methanol in fuel cells operating with direct methanol. Basically, there is unusually low temperature combustion of methanol in the fuel cell, i.e. oxygen in the air generates water and carbon dioxide from methanol. Energy released from the fuel cell during combustion is extracted as electricity rather than thermoenergy.

The total reaction taking place in the cell is:

$$
\mathrm{CH}_{3} \mathrm{OH}+3 / 2 \mathrm{O}_{2} \rightarrow \mathrm{CO}_{2}+2 \mathrm{H}_{2} \mathrm{O}, \mathrm{Erev}=1.18 \mathrm{~V}
$$

\section{Innovative Options for Methanol Production}

\section{Carbon Recycling International (CRI)}

CRI's George Olah Renewable Methanol Plant in Svartsengi, near Grindavik, Iceland began production in late 2011 and was completed in 2012. CRI is the first company in the world to produce renewable fuels (methanol) from carbon dioxide emissions on commercial level. Carbon cycle rotation and recycling, which has only been found in nature so far, can be achieved with this method. However, photosynthesis is a slow process. Plants are able to reproduce themselves using solar energy by recirculation of atmospheric carbon dioxide. The problem is that millions of years are needed to produce fossil fuels from the plant. People cannot wait for it, so we need a recycling option. It is a major challenge to produce hydrocarbon fuels efficiently and economically from water and carbon dioxide. Carbon Recycling International collects carbon dioxide emitted by geothermal power plants and then with the electricity generated in the particular power plant produces methanol by using $\mathrm{H}_{2}$ generated from electrolysis of water and the collected $\mathrm{CO}_{2}$. Recycling $\mathrm{CO}_{2}$ reduces net greenhouse gas emissions, and such a costeffective $\mathrm{CO}_{2}$ conversion to fuel makes sustainable production of renewable fuels possible. In contrast to the area requirements for the production of other alternative fuels such as bioethanol or biodiesel, renewable methanol production technology by CRI requires a small area of land; moreover, it does not participate in the competition for the use of scarce agricultural resources. The plant in Iceland currently produces 4,000 tons of methanol per year and they are planning to build additional factories in China and Europe. In 2015, Chinese carmaker Geely, which owns the Volvo brand, invested \$45M, so they became CRI's major shareholder. Mitsubishi-Hitachi Power Systems Europe (MHPSE) co-operates with CRI to find industrial solutions for carbon dioxide capture and renewable methanol production (Carbon Recycling International). The invention of the Nobel laureate György Oláh is generating more and more innovations.

\section{The Role of Methanol in Solving Waste Problem}

Material lifestyle of mankind is leading to a steady increase in global energy consumption, which is accompanied by the materiality of industrialized countries. If there is no change in current production and consumption processes, placing the ever-accumulating waste becomes an insoluble problem. As a result of the rapid growth and urbanization of the Earth's population, the amount of greenhouse gas emissions from waste - especially methane gas $\left(\mathrm{CH}_{4}\right)$ from landfills - is increasing. The short-term heat trap role of methane gas is significant: 72 times more per ton than that of the carbon dioxide. Reducing methane gas emissions in the fight against climate change is extremely important since methane gas is the second most significant greenhouse effect of human origin after carbon dioxide. At present production and consumption levels, the Earth's surface will soon be too small for landfilling; moreover, using Earth as a landfill is not a productive process. According to Blue Economy, it is natural that a living organism produces waste, but no natural system has waste output (Pauli, 2010). It is a business model that combines innovation and waste elimination in the most radical way. As such, waste acts as a raw material for industry; research into new raw materials and technologies is driven by the increasing energy demand and the intention to support environmental sustainability. Emerging environmental and ethical issues advance the use of second generation biofuels (motor fuels derived from non-food based, lignocellulosic, biomass-based synthesis gas, by solid biomass liquefaction, with algae).

\section{Production of Methanol from Communal Waste}

In 2011, 'World Competition of Green Inventions' was organized at one of the most significant innovation exhibitions in the world (IENA). Two Hungarian creators, Iván Raisz and István Barta, were awarded the main prize of the competition, the 'Green Oscar', for their invention Methanol Synthesis from Communal Waste (greenfo, 2011). The principle of the invention is that methyl alcohol is produced via synthesis gas using waste containing organic solvents. Solid communal waste, sewage sludge and biomass waste can be used as base materials, which are converted to carbon dioxide, carbon monoxide and hydrogen in a fixed-bed gasifier under the influence of oxygen, water vapour, contaminated water and tar generated during the process. When using communal waste, inorganic materials are first sorted from the incoming waste and then organic materials are chopped. Wastes of different compositions are mixed in an appropriate proportion, then compressed and led to a gas generator. Five percent of solid vitreous slag and a gas mixture are formed during this process. Hydrogen chloride and dihydrogen sulphide are removed from the gas mixture leaving the generator, and water vapour is condensed. The thus purified gas is passed through a catalyst filled tube. The resulting methanol is $43 \%$ by weight of the feedstocks and its water content is less than $2 \%$. Electricity needed for hydrolysis is provided by using a proportion of the purified gases in a gas engine during the process. Oxygen generated during hydrolysis is led to the generator and hydrogen is used to adjust the ratio of $\mathrm{CO} \mathrm{H}_{2}$ of the gas mixture in the methanol reactor. Further advantage of the invention is that dioxins and tar are not produced in this process unlike during combustion of conventional waste (Raisz, 2007).

\section{Production of Methanol from Agricultural Waste}

A lot of organic waste is produced during agricultural production, for example, $99.8 \%$ of the total biomass becomes waste after harvesting coffee beans. US surveys show that a single unit of industrial, mining, and agricultural waste management is seventy times more expensive than municipal waste management. Waste from agricultural production is typically biomass and 
the plastics required for work (foil e.g.), or animal husbandry waste, i.e. dung water.

Methanol production technology for the recovery of agricultural waste can be divided into two parts:

1. synthesis gas production from waste;

2. production of methanol from synthesis gas.

Production of methanol from synthesis gas dates back almost a hundred years as the method was developed by BASF in in Germany the 1920s. Gas mixtures containing carbon monoxide and hydrogen were converted to methanol by applying a suitable pressure and temperature, and a catalyst.

Chemical reaction equation:

$$
\mathrm{CO}+2 \mathrm{H}_{2}=\mathrm{CH}_{3}-\mathrm{OH}
$$

On an industrial scale, up to $98 \%$ of material output can be achieved, so there is almost no by-product, no more waste generated. A condition of proper material exploitation is that carbon monoxide: hydrogen mass ratio is $7: 1$.

There are several options to achieve the correct weight ratio: for example, using an adequately selected waste mixture or the incorporation of a hydrolyser that utilizes solar or wind power.

Waste gasification is performed with a Plasma Gasification Vitrification Reactor. Its extraordinary advantage is that it greatly increases productivity since molecular bonds break immediately and diatomic gases, typically carbon monoxide and hydrogen, are formed due to well-chosen Planck radiation (Kozéky, 2012). The amount of biomass in a $25 \mathrm{~km}$ radius is sufficient for the economical operation of a plant which is operated by connecting a Plasma Gasification Vitrification Reactor and an equipment using syngas; and organic materials from regional selective waste plants can also be used as raw materials, thus the capacity utilisation of the plant can be fulfilled by the use of regional waste.

Methanol economy can contribute to reducing human impacts on Earth's climate by reversing atmospheric carbon dioxide, and it provides the opportunity to get rid of our dependence on dwindling oil and gas resources. The use of waste as a raw material can increase if the efficiency of the sector is increased; it requires new innovative methods and technologies. With effective politics and intensive innovation activities, we have a chance to change faster than the climate.

\section{References}

ADAMS, W.M. 2006. The future of sustainability: Re-thinking Environment and Development in the twenty-first century. https://cmsdata.iucn.org/downloads/ iucn_future_of_sustanability.pdf

AUSTIN, J. 2014. Growing Michigan's Blue Economy.

CARBON RECYCLING INTERNATIONAL. http://carbonrecycling.is/

GREENF0. http://greenfo.hu/hirek/2011/11/01/magyaroke-a-green-oscar

KOZÉKY, L. 2012. Zárt ciklusú hulladékgazdálkodási rendszerek. In Via Futuri 2012 Konferencia Pécs, Hungary, november 30, 2012.

MAILlER, M. 2008. Sustainability Assessment of an IAIA, The Art and Science of Impact Assessment, Perth (Western Australia): $28^{\text {th }}$ Annual Conference of the 125

PAULI, G. 2010. A Kék Gazdaság. Pécs : PTE KTK.

PAULI, G. 2015. The Blue Economy. Report to the Club of Rome. http://www. theblueeconomy.org/principles.html

POPE, J. et al. 2004. Assessment for sustainability. In Environmental Impact Assessement, Review, 2004, no. 24, pp. 595-616.

PORTER, M. E. 1991. America's Green Strategy. Scientific American. 264, no. 4

TUKKER, A. - TISCHNER, U. 2006. New Business for Old Europe. Product Services, Sustainability and Competitiveness. Sheffield, UK: Greenleaf Publishing Ltd.

UNITED NATIONS FRAMEWORK CONVENTION ON CLIMATE CHANGE KYOTO PROTOCOL: http://unfccc.int/kyoto_protocol/items/2830.php

W00D, C. 2002. Environmental Impact Assessment-Process Practice and Performance. Manchester: Institute of Environmental Management and Assessment, Environmental Assessment Yearbook 2002.

\section{Contact address}

Judit Toth, PhD student

Doctoral School of Management and Business Administration

Szent István University

Faculty of Economics and Social Sciences

H-2100 Gödöllő, Páter Károly street 1

e-mail: toth.judit@adepto.hu 